\title{
The Level of Thermal Comfort in Residential Houses Based on the Shape, Orientation and Material of Roof Cover in Kampong (Case Study: RT.05/RW.04, Kamal, Kalideres, Jakarta Barat)
}

\author{
Anggraeni Dyah Sulistiowati \\ Dept. of Architecture \\ Universitas Budi Luhur \\ Jakarta, Indonesia \\ anggraeni.dyah@budiluhur.ac.id
}

\author{
Betaviane Indah Putri \\ Dept. of Architecture \\ Universitas Budi Luhur \\ Jakarta, Indonesia \\ annebetavianne@gmail.com
}

\begin{abstract}
Kampung Kota (KK) is a form of urban area settlement in Indonesia. KK is a characteristic of big cities that still carry the environment and behavior of rural life, dense buildings, densely populated. Also, urban villages are characterized by low per capita income, developing without regular patterns. In terms of physical comfort, houses in urban villages are generally not by thermal and visual (light) comfort requirements. RT.05 / RW.04 Kamal Village, Kalideres District, West Jakarta, is one of the most problematic urban villages in DKI Jakarta. One of the problems at the location (RT.05/RW.04) is thermal comfort, which is under the standards (SNI T-14-1993-037). For this reason, this research is needed. This study is conducted to measure the level of thermal comfort in residential homes in RT.05/RW.04. Measurements were made based on the shape, orientation, and material of the roof covering. The roof was chosen as a benchmark because the roof is one of the media for the entry of solar radiation into the building. The purpose of this study was to determine the level of thermal comfort in households in KK based on the shape, orientation and material of the roof covering. This research uses a quantitative method with an experimental approach. The quantitative method is done by grouping the house based on the shape, orientation, and material of the roof. Then each house's thermal comfort level is measured. The measurement results are used to determine the effect of the shape, orientation, and material of the roof covering the thermal comfort level of households in KK. The results of this study are the recommendation of the shed roof to absorb less heat than the hip and gable roof. The orientation of the roof facing west and east absorbs less heat than the orientation of the north and south roofs. Clay tile roof covering material absorbs less heat than the asbestos material.
\end{abstract}

Keywords: Kampung Kota, thermal comfort, roof shape, roof orientation, roof material

\section{INTRODUCTION}

The total land area for housing in DKI Jakarta in 2015 was divided into two parts, $27.5 \%$ planned housing and $72.5 \%$ unplanned housing [1]. The majority of Jakarta's immigrant population are low-income people who live in KK. Furthermore, KK is part of unplanned housing. In addition to being inhabited by low-income people, many residents of the $\mathrm{KK}$ are referred to as having low education. $\mathrm{KK}$ also often feels that housing is not healthy [2].
One of the KKs in DKI Jakarta is in area RT.05/RW.04. The KK is located in Kelurahan Kamal, Kecamatan Kalideres, Jakarta Barat. These KKs are villages with irregular settlement patterns, high population density, high building density, and residents with low per capita income. The limited density of land and the low level of education resulted in maximum residential use areas being built for buildings. This results in homes not meeting the comfort requirements of the building.

The community RT.05/RW.04 states, from midday to evening, the air inside the residence feels very hot. This condition occurs because the house does not use a ceiling, so the solar's heat entering through the roof directly into the room. Besides, there are not many residential houses that do not use a cross-ventilation system. This is because openings for ventilation are only available at the front of the house. The absence of ceiling and cross ventilation systems is the most significant factor in the increase in temperature in the house.

The air temperature inside is not according to the thermal comfort standard in Indonesia by SNI T-14-1993-037. There are several benchmarks for thermal comfort standards for humid tropical climate regions, one of which is effective temperature. The effective temperature is a combination of temperatures measured by a thermometer, humidity, and wind velocity. These three measurements give the skin a warm or cold sensation and are declared comfortable or uncomfortable [3].

According to SNI T-14-1993-037 the standard thermal comfort zone in Indonesia based on effective temperature is uncomfortably cool (TE) at temperatures $<20.5^{\circ} \mathrm{C}$; comfortable cool (TE) between temperatures $20.5^{\circ} \mathrm{C}-22.8^{\circ} \mathrm{C}$; optimal comfort (TE) between temperatures $22.8^{\circ} \mathrm{C}-25.8^{\circ} \mathrm{C}$; warm comfortable (TE) between temperatures $25.8^{\circ} \mathrm{C}$ $27.2^{\circ} \mathrm{C}$; and uncomfortable heat (TE) at temperatures $>$ $27.2^{\circ} \mathrm{C}[4]$.

Meanwhile, according to Georg Lippsmeier's research, factors that affect the comfort, mental abilities, and physical occupants are solar radiation, reflection and absorption, temperature and temperature changes, air humidity, and air movement [5]. The solar heat enters the building through roofs, walls, floors, and windows. Solar heat entering the 
building through the roof is being affected by the shape, orientation, and material of the roof covering.

The main problem in houses in RT.05/RW.04 is thermal comfort. For this reason, a study related to thermal comfort was carried out by measuring the effective temperature at the residence. Because the sun's heat entering the building is dominated by the roof, effective temperature measurements are based on the shape, orientation, and material of the roof. The aim of this study is to determine the effect of roof shape, orientation and material on the thermal comfort level of residential houses in RT.05/RW.04.

\section{LITERATURE REVIEW}

Thermal comfort in residential homes in RT.05/RW.04 is measured using effective temperature benchmarks. The effective temperature is a combination of temperature measurements measured by a thermometer, humidity, and wind velocity. The third measurement is the measurement of something that causes a warm or cold sensation on the skin. The statements "comfortable" and "uncomfortable" are the results of these effective temperature measurements. The effective temperature is calculated based on the correlation curve between temperature and humidity [3].

The problem of hot air from afternoon to evening in residential homes in RT.05/RW.04 due to solar heat entering through the roof. Solar heat goes down directly to the room because the house does not use any ceiling. Because the building has ventilation only on the front side of the house, there is no cross ventilation, which helps to expel solar heat from the building. Thus the effective temperature measurement in residential houses in RT.05/RW.04 only measures air temperature and humidity in buildings. Wind velocity is not measured because there is no cross ventilation in the building.

Standard thermal comfort zone in Indonesia based on effective temperature by SNI T-14-1993-037 are [4] :

1. Uncomfortably cool (TE) : $<20.5^{\circ} \mathrm{C}$ TE

2. Comfortable coo (TE) $: 20.5^{\circ} \mathrm{C} \mathrm{TE}-22.8^{\circ} \mathrm{C}$ TE

3. Optimal comfort (TE) $\quad: 22.8^{\circ} \mathrm{C} \mathrm{TE}-25.8^{\circ} \mathrm{C} \mathrm{TE}$

4. Warm comfortable (TE) $: 25.8^{\circ} \mathrm{C} \mathrm{TE}-27.2^{\circ} \mathrm{C}$ TE

5. Uncomfortable heat (TE) : $>27.2^{\circ} \mathrm{C}$ TE

The main problem in houses in RT.05/RW.04 is thermal comfort. For this reason, a study related to thermal comfort was carried out by measuring the effective temperature at the residence. Because the sun's heat entering the building is dominated by the roof, effective temperature measurements are based on the shape, orientation, and material of the roof. The results of this research will determine the effect of the shape, orientation, and material of the roof cover on the level of thermal comfort of households in KK.

\section{RESEARCH METHOD}

This research uses a quantitative method with an experimental approach. The quantitative method is done by grouping the house based on the shape, orientation, and material of the roof in RT.05/RW.04 Kelurahan Kamal Kecamatan Kalideres Jakarta Barat [6]. While the experimental approach is carried out by measuring air temperature and humidity based on the group shape, orientation, and roof material. The measurement results are used to determine the effect of the shape, orientation, and material of the roof covering the thermal comfort level of households in KK [7] dan [8].

Houses measured by air temperature and humidity are selected using purposive sampling. The method purposive sampling is based on the criteria of the shape, orientation, and material of the roof in single-storey buildings, without ceilings with a building area between 50-80 $\mathrm{m} 2$. Measurement of air temperature and humidity is done by:

1. 30 days ( 1 month) measurement

2. Morning (08.00WIB) measurement, noon (12.00WIB) measurement, and afternoon (16.00WIB) measurement

RT.05/RW.04 has an area of 3.1 hectares, 567 inhabitants, and 202 houses (Figure 1).

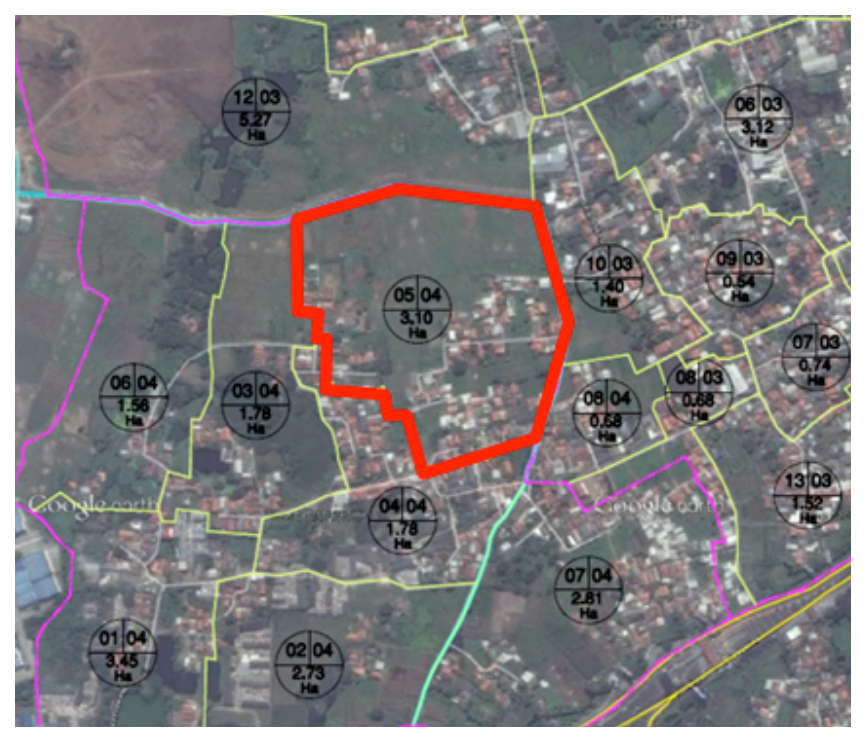

Fig. 1. RT.05/RW.04

There are 3 different roofs use by the house in RT.05/RW.04:

1. Shed roof, which is a roof plane consisting of one side roof.

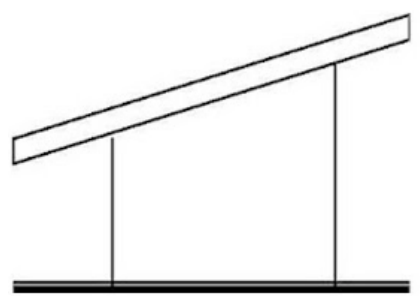

2. Gable roof, which is a roof plane consisting of two side roof.

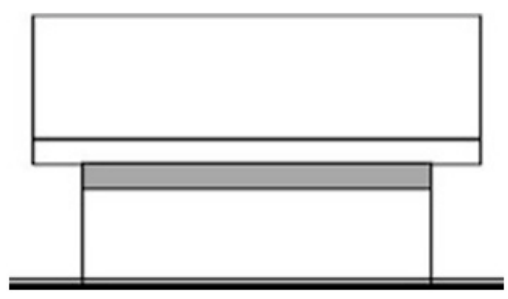


3. The hip roof, which is a roof plane consisting of four side roof.

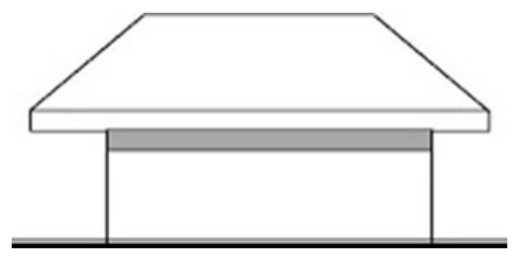

There are 2 different roof materials use by the house in RT.05/RW.04:

1. Clay Tile

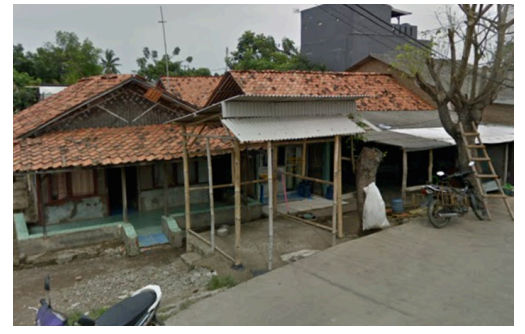

2. Asbestos

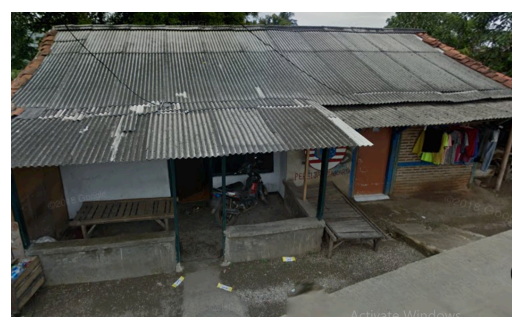

Case studies were selected according to the purposive sampling sample's method. Case selection is based on the similarity of the house to the roofing, orientation and material grouping. There are eight case studies based on these groupings consisting of:

1. Two houses with shed roof shape, with an orientation to the west-east and north-south, respectively. At RT.05/RW.04 there are no shedroofed houses that use clay tile material because it is heavy so it quickly falls. All roofs use asbestos material.

2. Four houses with a gable roof shape, orientation to the west-east, and north-south, respectively. The roofing materials used are clay and asbestos, respectively.

3. Two houses with hip roofs, and roofing materials, each clay, and asbestos tile. There is no east-west and north-south orientation because the hip roof has four sides facing the four cardinal directions.

\section{RESULTS AND DISCUSSION}

From the purposive sampling sample method, there are eight case studies of residential houses based on the similarity of the house to the shapes, orientations, and roof covering material (Figure 2).

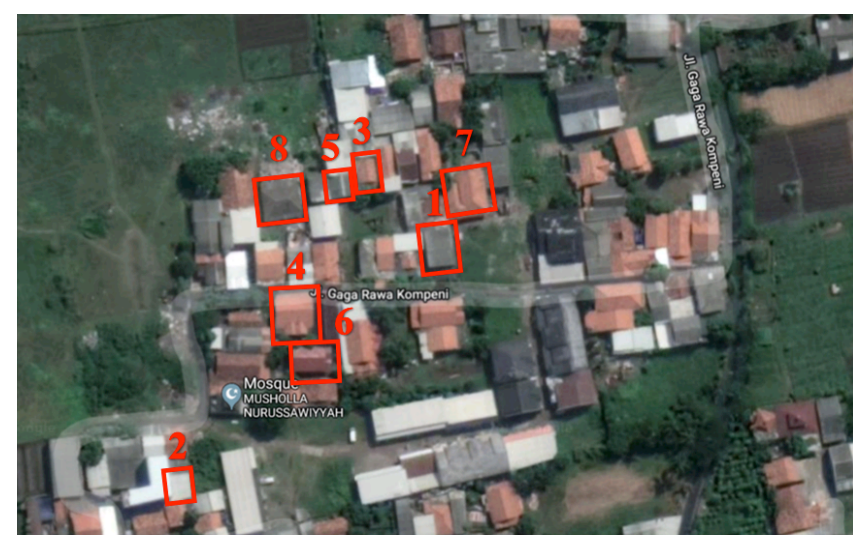

Fig. 2. Case Studies Location (RT.05/RW.04)

Eight cases in RT.05/RW.04 :

1. Shed roof, asbestos material, west-east orientation
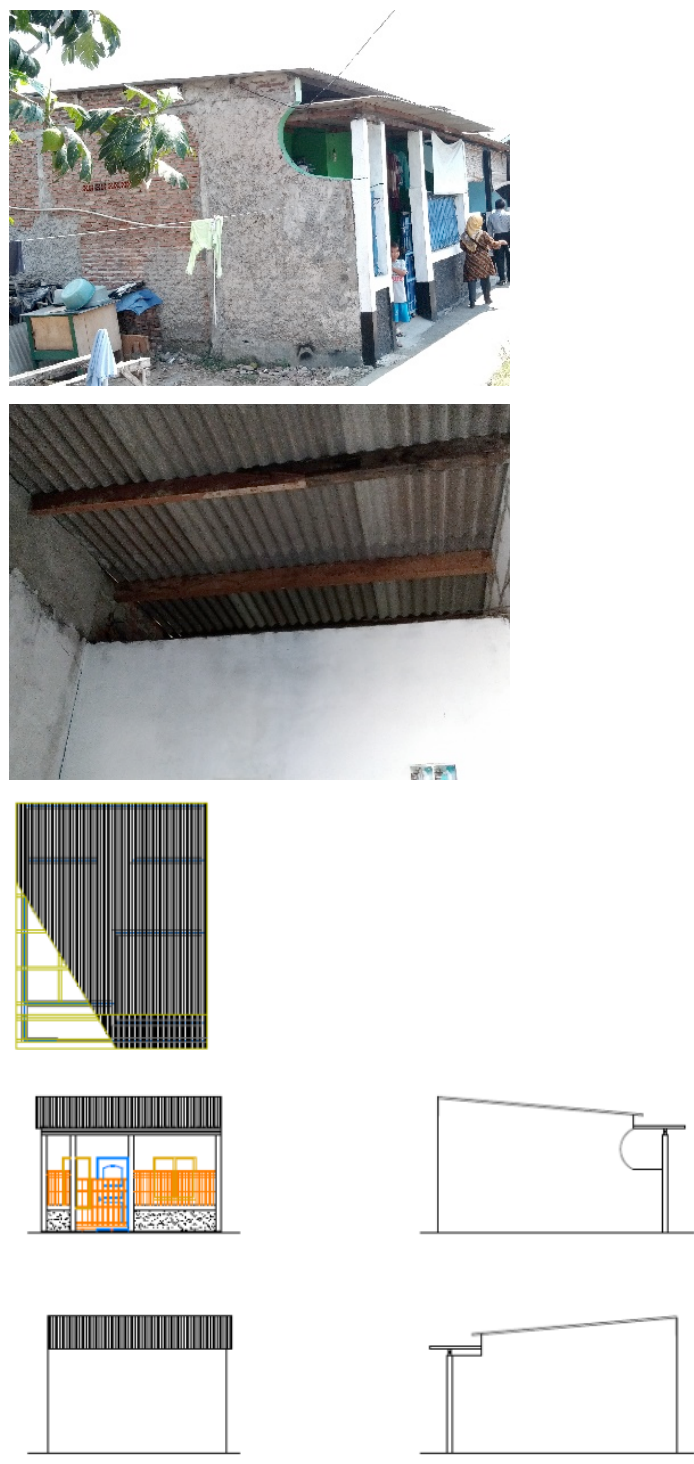


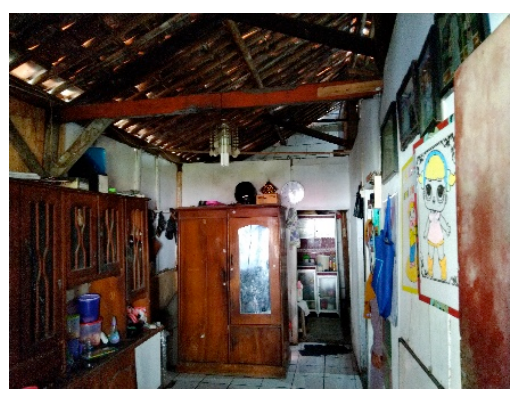

2. Shed roof, asbestos material, north-south orientation
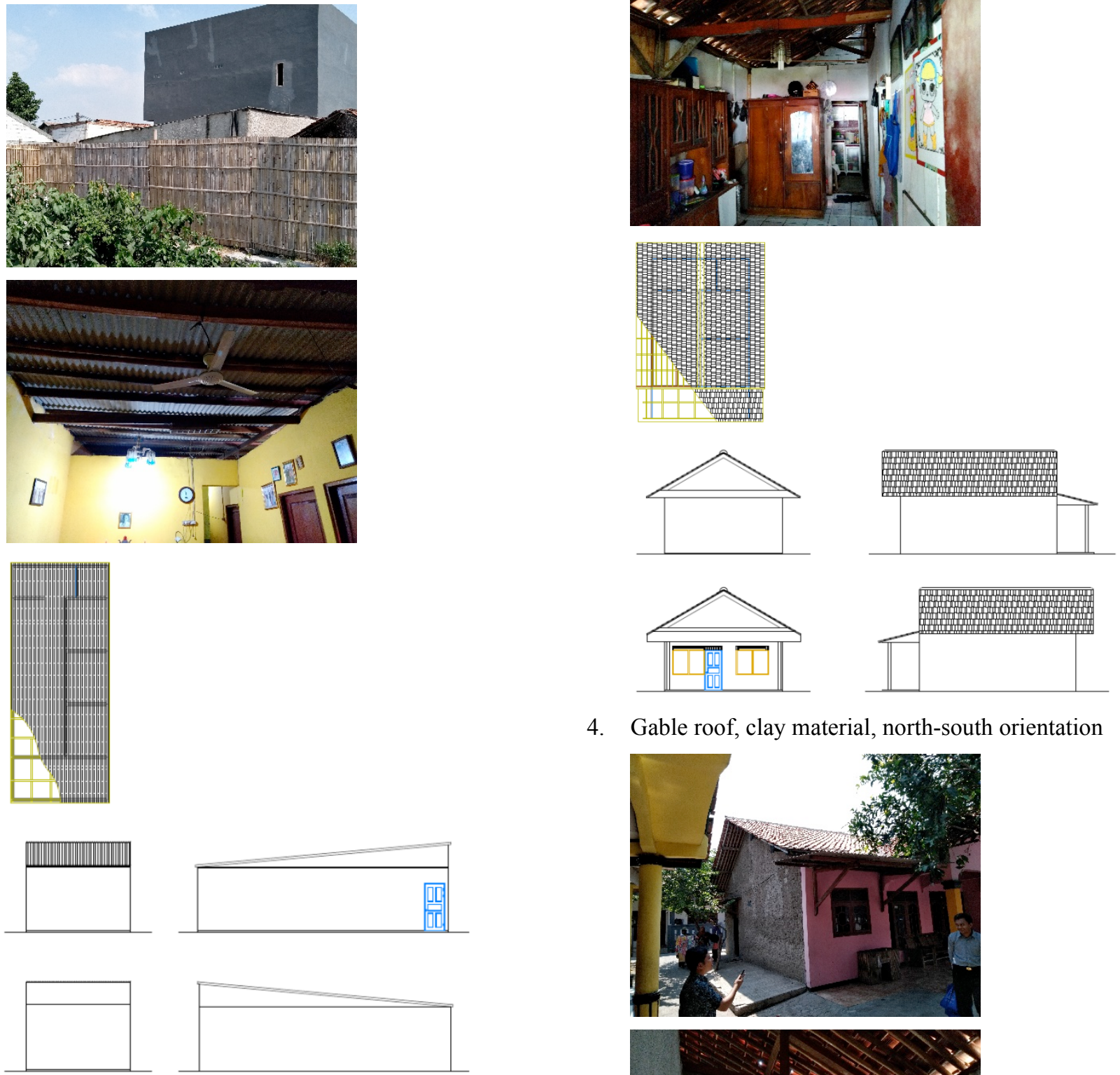

3. Gable roof, lay material, west-east orientation
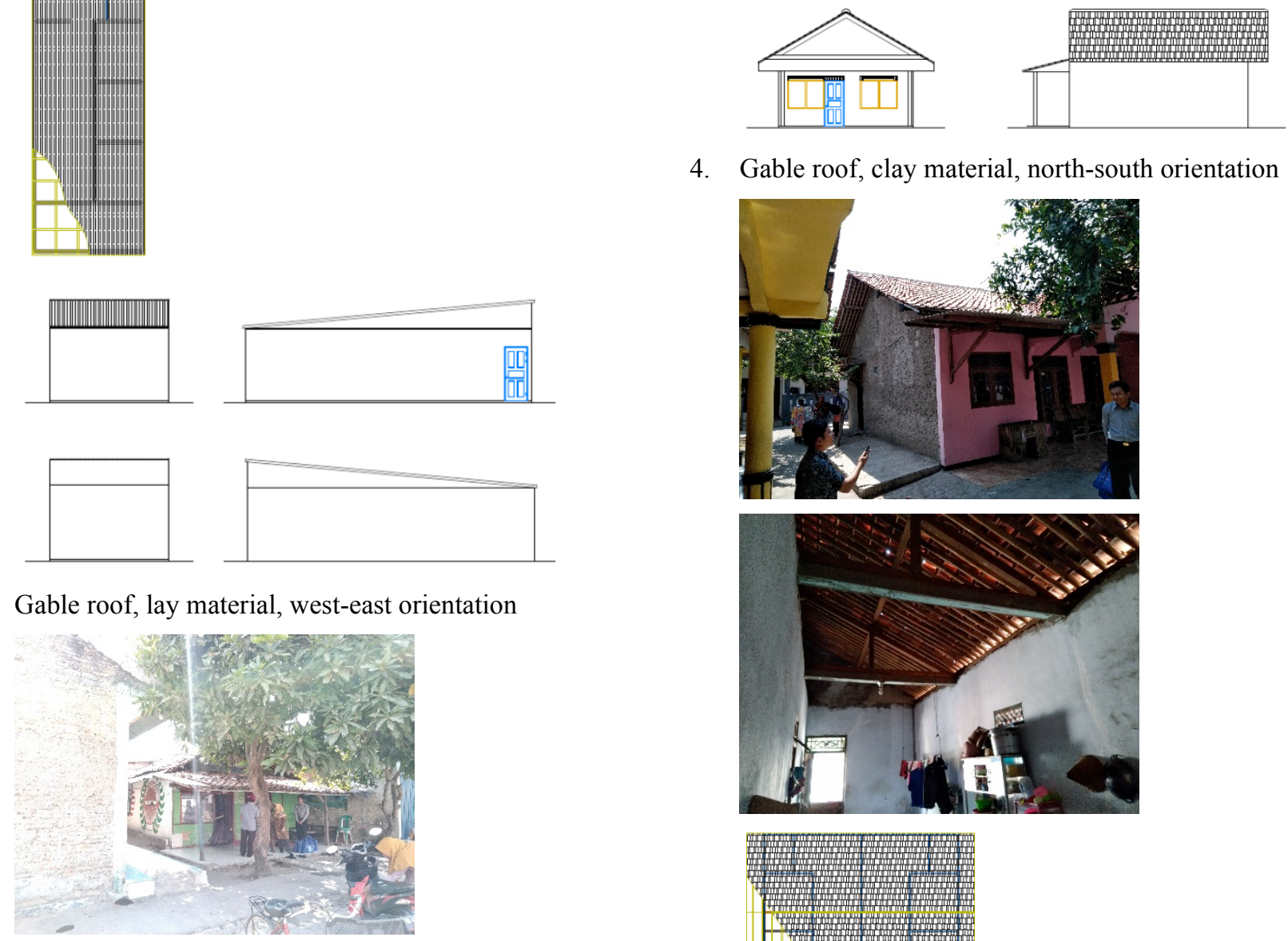

4. Gable roof, clay material, north-south orientation
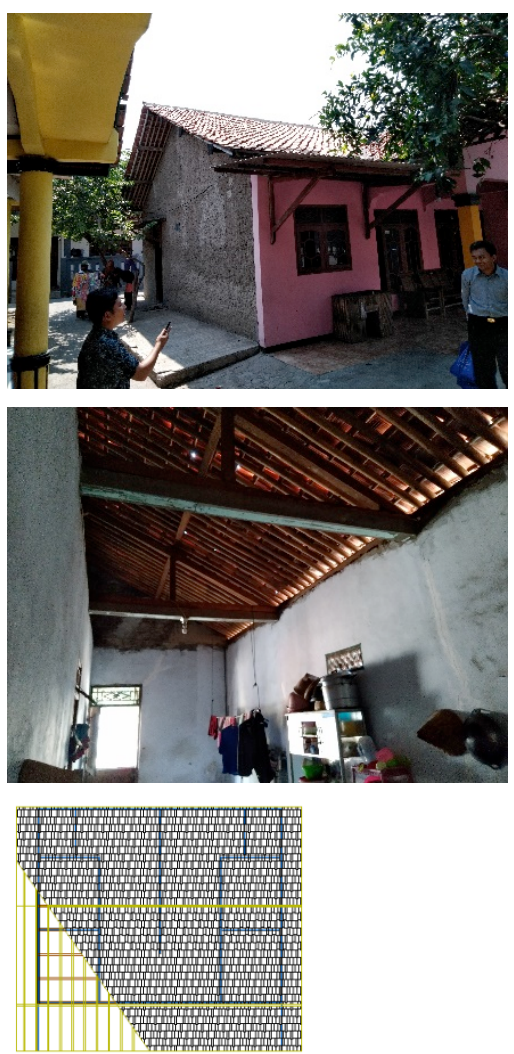

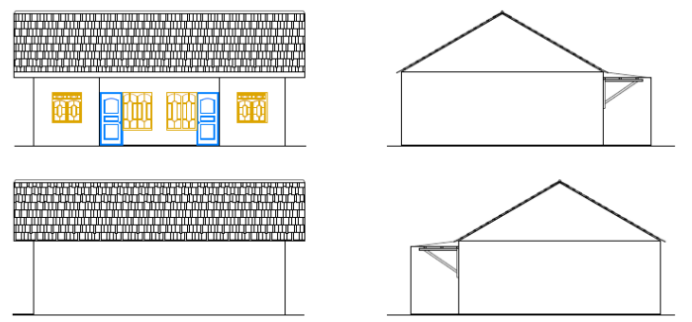

5. Gable roof, asbestos material, west-east orientation
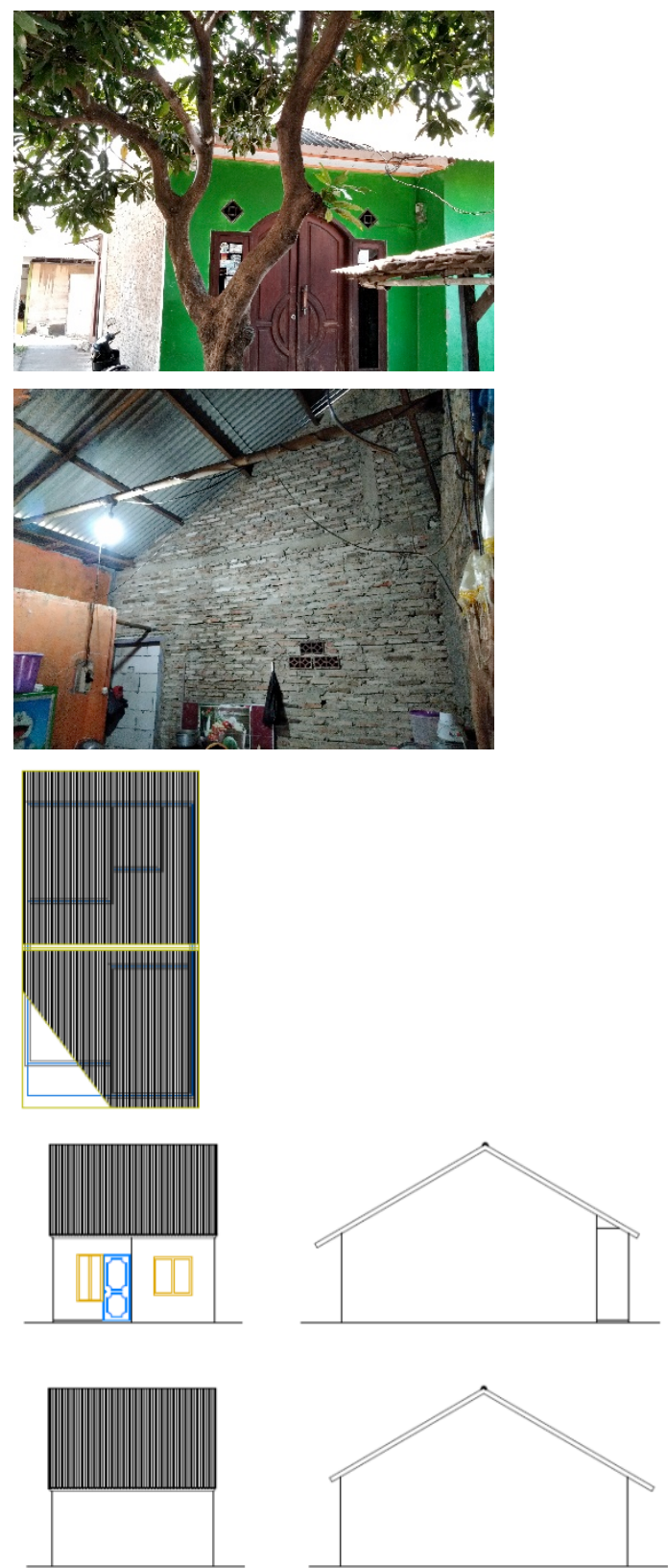

6. Gable roof, asbestos material, north-south orientation
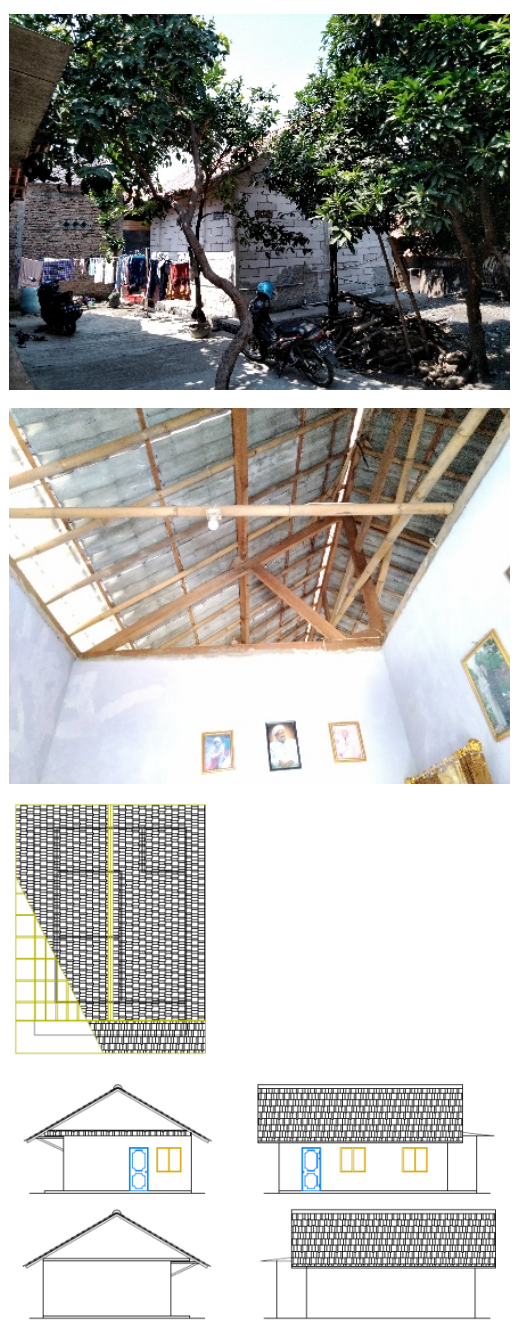

7. Hip roof, clay material
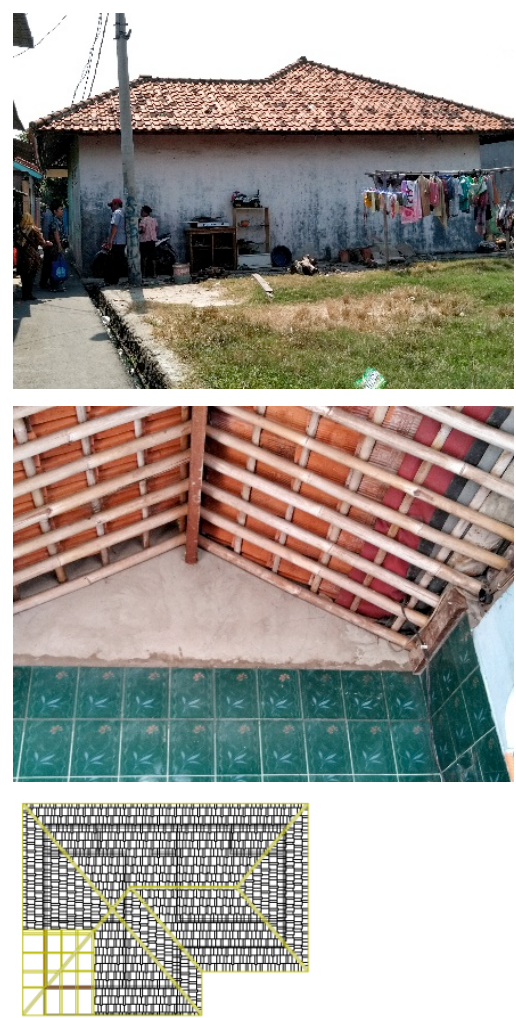

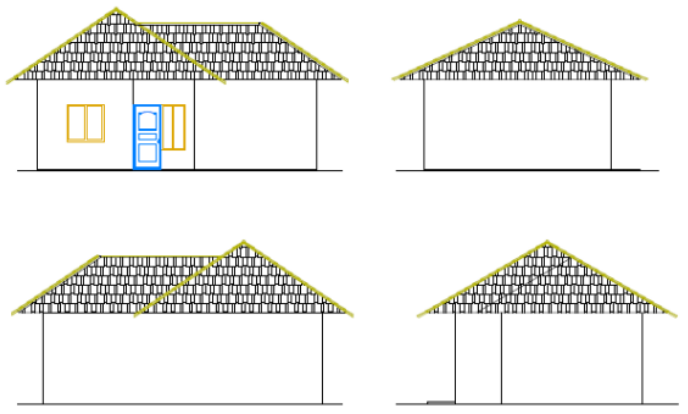

8. Hip roof, asbestos material
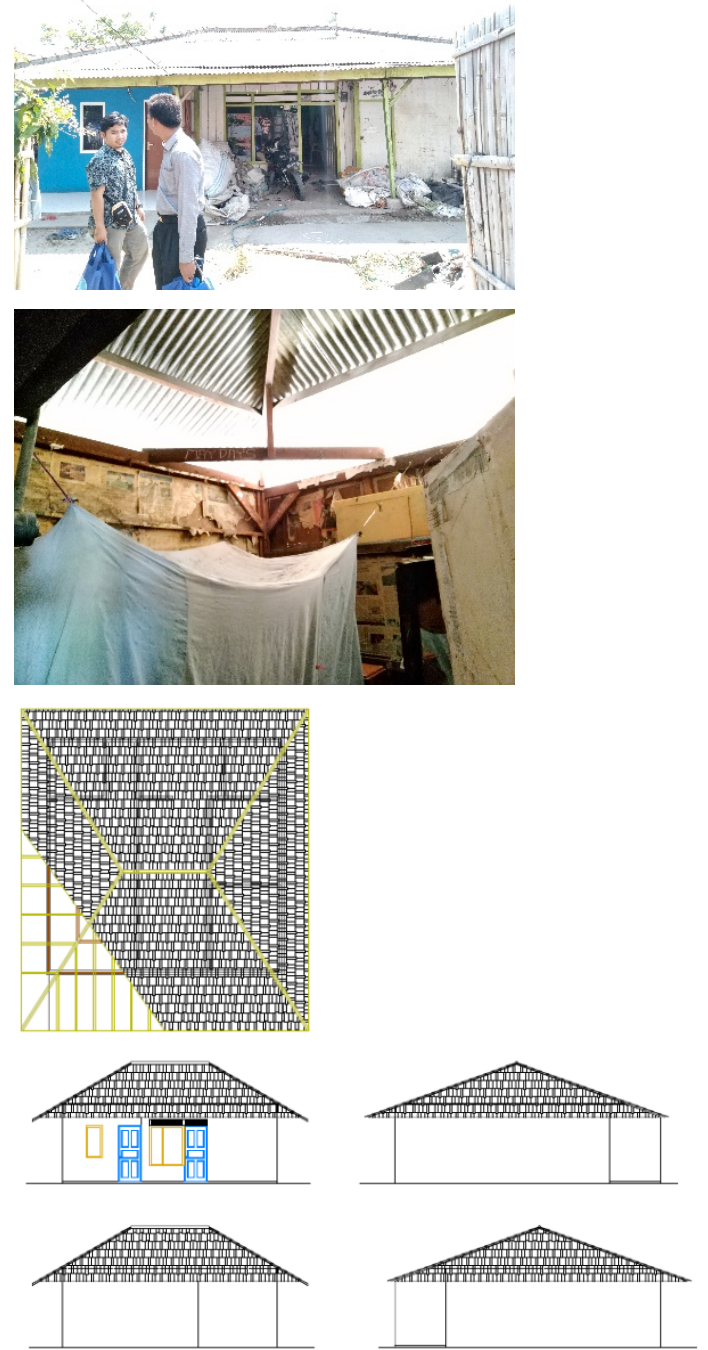

The measurement of air temperature in eight case studies of residential houses in RT.05/RW.04 was conducted for thirty days in the morning, afternoon, and evening. The results of air temperature measurements are calculated on average to obtain average temperatures per day. The results of the average air temperature for thirty days are calculated on average to obtain the average air temperature per case home study (Figure 3).

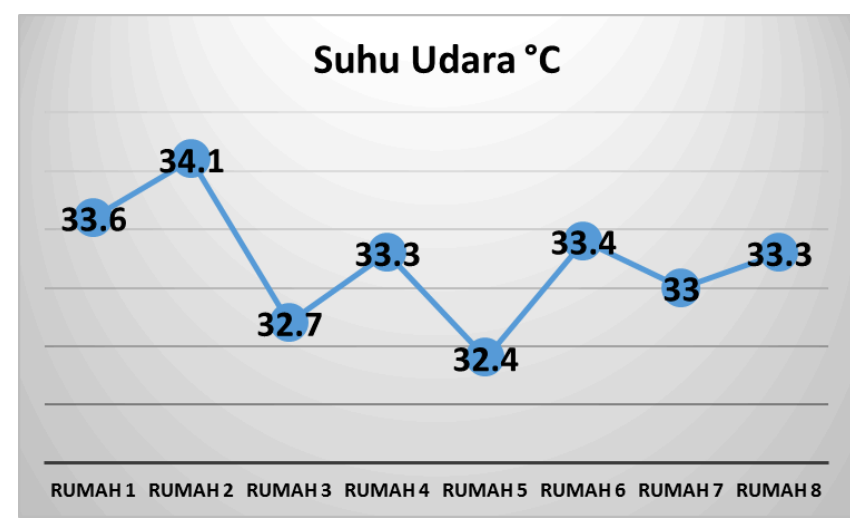

Fig. 3. Air Temperature in 8 Houses in RT.05/RW.04

The results of the average air temperature measurements are obtained due to the influence of the shape, orientation, and roof material on the air temperature of the residence. The shape of the gable roof has the lowest average temperature of $32.9{ }^{\circ} \mathrm{C}$. Furthermore, the shape of the hip roof has an average air temperature of $33.1{ }^{\circ} \mathrm{C}$. The shape of the shed roof has the highest average air temperature of $33.8{ }^{\circ} \mathrm{C}$. While in terms of orientation, the orientation of the east-west roof has the lowest average air temperature of $32.9{ }^{\circ} \mathrm{C}$. While the orientation of the north-south roof has the highest average air temperature of $33.5{ }^{\circ} \mathrm{C}$. In terms of roofing material, clay roof tile material has the lowest average air temperature of $32.7^{\circ} \mathrm{C}$ while asbestos roof covering material has the highest average air temperature of $33.3^{\circ} \mathrm{C}$.

Humidity measurements in eight case studies of residential houses in RT.05/RW.04 were carried out for thirty days in the morning, afternoon, and evening. The results of humidity measurements in the morning, afternoon, and evening are calculated on average to obtain average humidity per day. The average humidity yield for thirty days is calculated on average to obtain the average humidity per case study of a dwelling (Figure 4).

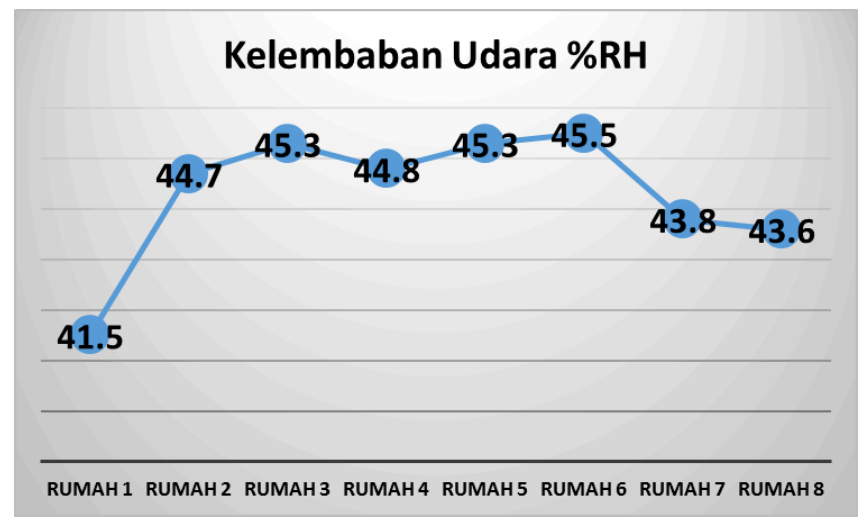

Fig. 4. Humidity in 8 Houses in RT.05/RW.04

The average humidity measurement results are obtained due to the influence of the shape, orientation, and material of the roof. The shed roof shape has the lowest average humidity of $43.1 \% \mathrm{RH}$, then the hip roof shape has an average humidity of $43.7 \% \mathrm{RH}$, and the gable roof shape has the highest average humidity of $45.2 \% \mathrm{RH}$. The east-west roof orientation has the lowest average humidity of $44 \% \mathrm{RH}$, and the north-south roof orientation has the highest average humidity of $45 \% \mathrm{RH}$. Asbestos roofing material has the 
lowest average humidity of $44 \% \mathrm{RH}$, and clay tile roof covering material has the highest average humidity of $44.8 \%$ RH.

Based on the results of measurements of air temperature and humidity in 8 case studies of residential houses in RT.05/RW.04, it is then calculated based on the effective temperature value of each case study of residential homes.

1. The effective temperature value in the case study of shed roof type houses, asbestos material, an eastwest orientation is $23^{\circ} \mathrm{C}$ TE

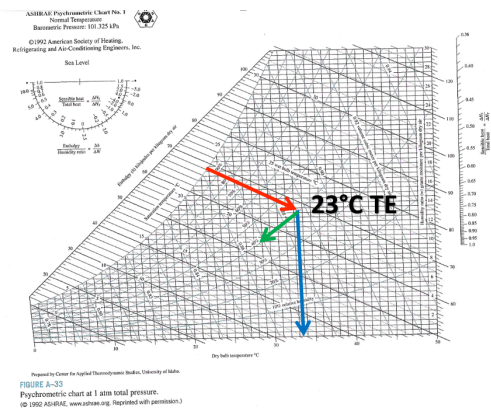

2. The effective temperature value in the case study of shed roof type houses, asbestos material, an northsouth orientation is $24.7^{\circ} \mathrm{C} \mathrm{TE}$

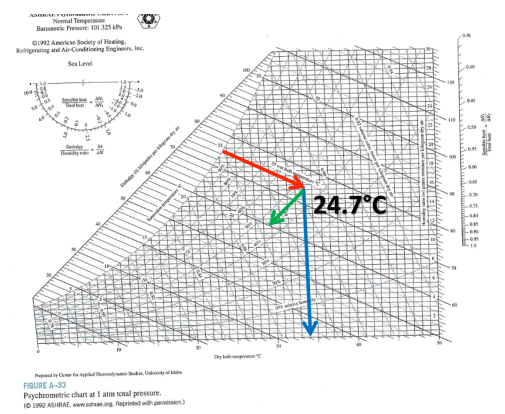

3. The effective temperature value in the case study of gable roof type houses, clay material, an west-east orientation is $23.2^{\circ} \mathrm{C} \mathrm{TE}$

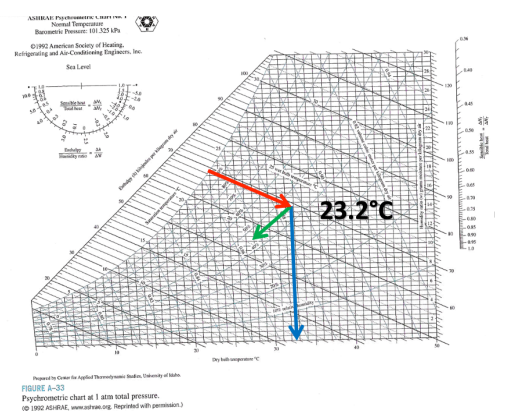

4. The effective temperature value in the case study of gable roof type houses, clay material, an northsouth orientation is $23.7^{\circ} \mathrm{C} \mathrm{TE}$

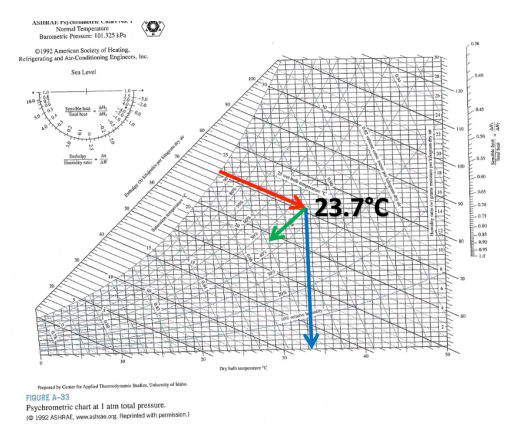

5. The effective temperature value in the case study of gable roof type houses, asbestos material, an westeast orientation is $23.2^{\circ} \mathrm{C} \mathrm{TE}$

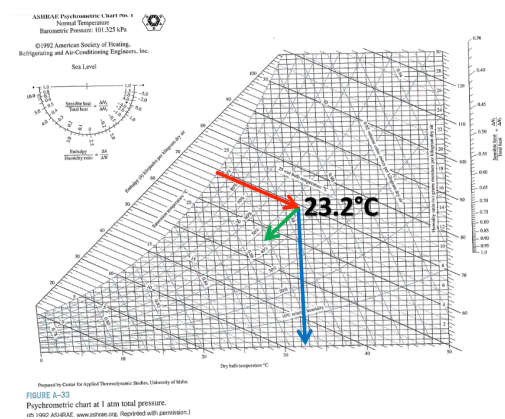

6. The effective temperature value in the case study of gable roof type houses, asbestos material, an northsouth orientation is $24.1^{\circ} \mathrm{C} \mathrm{TE}$

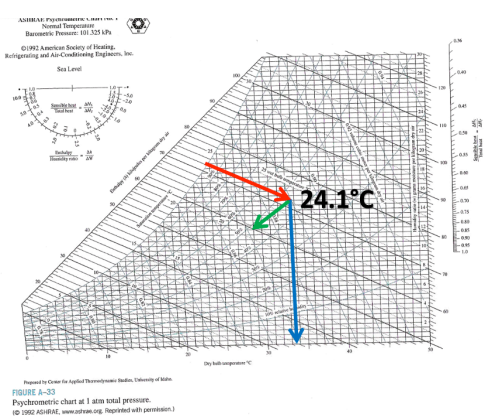

7. The effective temperature value in the case study of hip roof type houses and clay material is $23.5^{\circ} \mathrm{C} \mathrm{TE}$

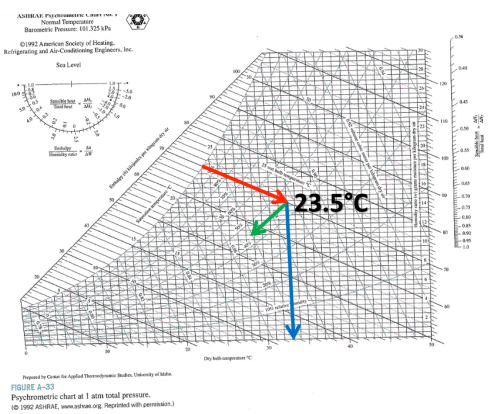

8. The effective temperature value in the case study of hip roof type houses and asbestos material is $23.8^{\circ} \mathrm{C}$ TE 


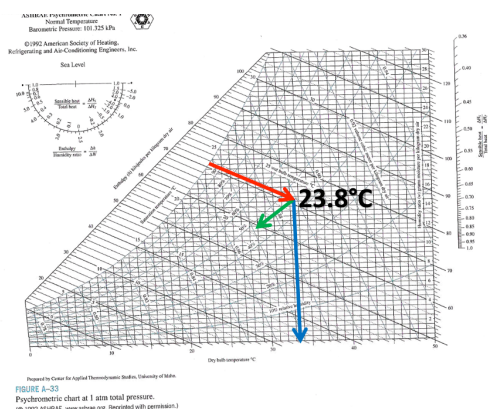

The result of effective temperature measurement in 8 case studies of residential houses, the lowest effective temperature of $23^{\circ} \mathrm{C} \mathrm{TE}$ in residential houses with shed roof shape, east-west orientation and clay roof cover material. While the highest effective temperature is $24.7^{\circ} \mathrm{C} \mathrm{TE}$ in residential houses with shed roof shape, north-south orientation and asbestos roof covering material, so based on the standard thermal comfort zone in Indonesia SNI T-141993-037 the value of the effective temperature of homes in RT.05/RW.04 is optimal comfort (TE), which is between $22.8^{\circ} \mathrm{C}$ TE $-25.8^{\circ} \mathrm{C}$ TE (Figure 5).

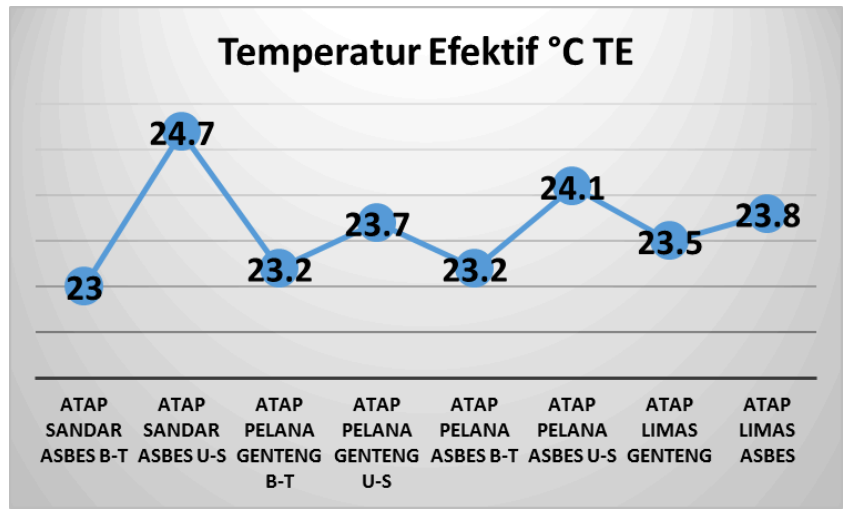

Fig. 5. Effective Temperature in House in RT.05/RW.04

From the measurement of the effective temperature in eight case studies of residential houses in RT.05/RW.04, it is known that the effect of the shape of the roof on the thermal comfort of homes in urban villages (Figure 6). The lowest effective temperature value is $23.5^{\circ} \mathrm{C} \mathrm{TE}$ in residential houses with gable roof form. Furthermore, the effective temperature value is $23.6^{\circ} \mathrm{C}$ TE in residential houses with hip roof shape while the highest effective temperature value is $23.8^{\circ} \mathrm{C} \mathrm{TE}$ in residential houses with shed roof shape.

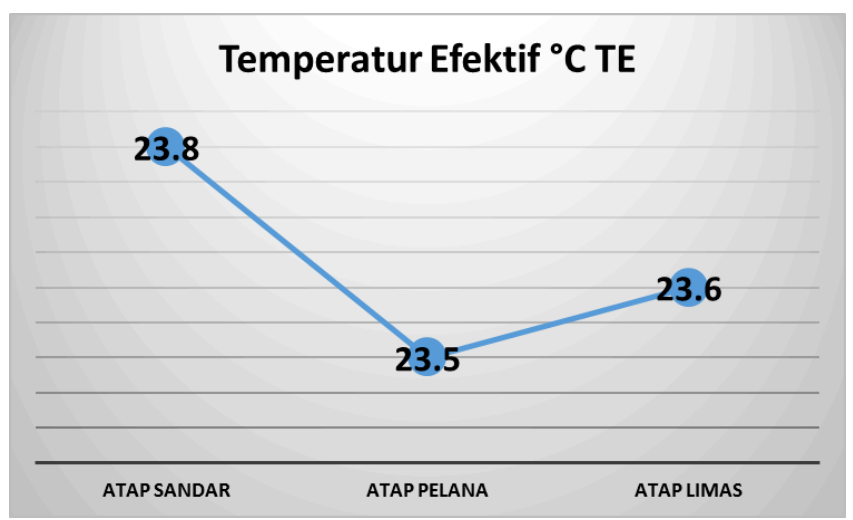

Fig. 6. Effective Temperature Based on Shape of Roof
From the measurement of effective temperature in eight case studies of residential houses in RT.05/RW.04, it is known that the effect of roof orientation on thermal comfort in residential homes in urban villages (Figure 7). The lowest effective temperature value is $23.1^{\circ} \mathrm{C}$ TE for residential with east-west roof orientation. Moreover, the highest effective temperature value is $24.1^{\circ} \mathrm{C}$ TE in a house with a north-south roof orientation.

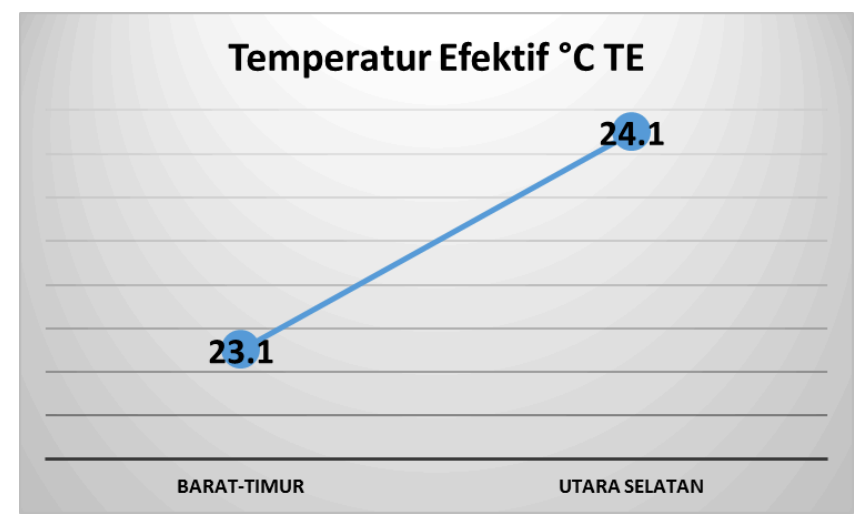

Fig. 7. Effective Temperature Based on Roof Orientation

From the measurement of effective temperature in eight case studies of residential houses in RT.05/RW.04, it is known that the influence of roof covering material on thermal comfort in residential homes in urban villages (Figure 8). The lowest effective temperature value of $23.4^{\circ} \mathrm{C}$ TE in residential homes with clay tile roof covering material. Furthermore, the highest effective temperature value of $23.7^{\circ} \mathrm{C} \mathrm{TE}$ in homes with asbestos roof covering material.

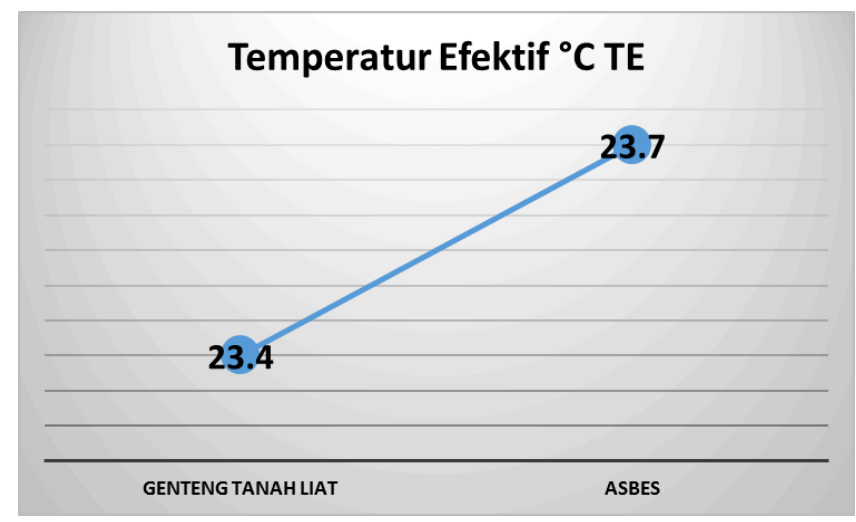

Fig. 8. Effective Temperature Based on Roof Material

From the results, there is the influence of the shape, orientation, and material of the roof on the value of the effectivity temperature in houses in RT.05/RW.04 (Figure 9). 


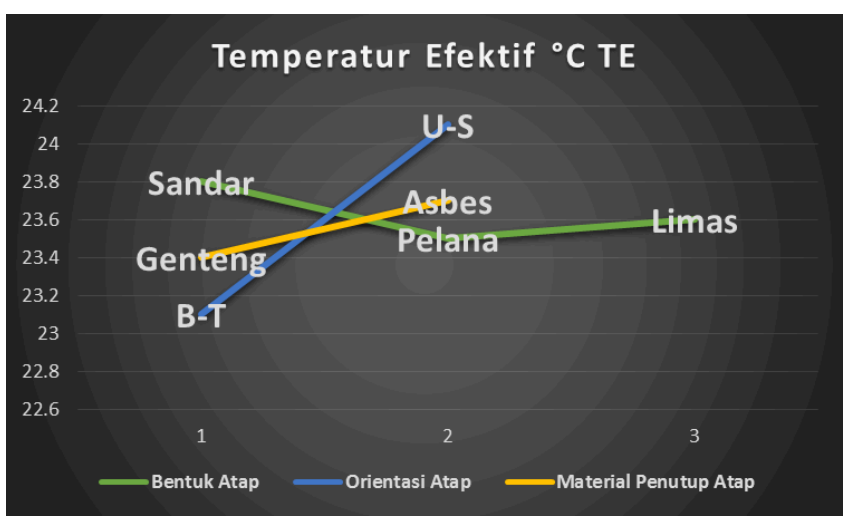

Fig. 9. Effect of Shape, Orientation and Roof Material on Effective Temperature Values

The shape of the gable roof has the lowest effective temperature value because it only has two sides of the roof, so only one side of the roof is exposed to the sun's heat. Furthermore, the shape of the hip roof has four sides of the roof, so that there are two sides of the roof that are exposed to the sun's heat. Moreover, the shape of the shed roof has the highest effective temperature value because it has one side of the roof so that the entire side of the roof is exposed to sunlight.

The east-west roof orientation has the lowest effective temperature value because the roof is exposed to the sun's heat in the morning until noon only or in the afternoon until the afternoon only. While the north-south roof orientation has the highest effective temperature value because the roof is exposed to the sun's heat all day from morning to evening.

Clay roof covering material has the lowest effective temperature value because it absorbs less heat from the sun while the asbestos roof covering material has the lowest effective temperature value because it absorbs more of the sun's heat.

\section{CONCLUSION}

Settlement in RT.05/RW.04 Kelurahan Kamal, Kecamatan Kalideres, Jakarta Barat is one of the Kampung Kota in DKI Jakarta. The biggest problem with the residential is thermal comfort in buildings that are not up to standard. Solar heat enters the building through the roof remains in the building because the house does not have a cross-ventilation system.
After measuring the air temperature and humidity in the cases, it is known the effective temperature value in each group of shapes, orientation and roof material. The influence of the shape of the roof on the effective temperature value is the shape of the gable roof has the lowest effective temperature value, then the shape of the hip roof and the shape of the shed roof has the highest effective temperature value. The effect of building orientation on the effective temperature value is the east-west roof orientation has the lowest effective temperature value and then the north-south roof orientation has the highest effective temperature value. The influence of the roof covering material on the effective temperature value is that the clay roof cover material has the lowest effective temperature value, and the asbestos roof material has the highest effective temperature value.

Thus there are the effects of the shape, orientation, and material of the roof on the thermal comfort of the house in a Kampung Kota. Furthermore, future research is needed related to how the roofing material can reduce solar heat. The research is needed so that homes in urban villages have thermal comfort under local standards.

\section{REFERENCES}

Nina Nurdiani, "Pola Pengembangan Rumah Di Kampung Kota Dan Faktor-Faktor Yang Mempengaruhinya," ComTech, vol. 1, no. 2, pp. 1041-1052, 2010.

[2] A. F. Nazaruddin, "Pertimbangan Berhuni pada Permukiman Kampung Dikota Malang," RUAS, vol. 15, no. 2, pp. 1-12, 2017.

[3] Febdian Rusydi, "Temperatur Efektif.” 2014.

[4] Atrium Architecture 10, "Standar Kenyamanan Termal, Visual, dan Audial." 2011.

[5] T. F. Nabil, "Kenyamanan Thermal." 2012.

[6] A. Hidayat, "Pengertian dan Penjelasan Penelitian Kuantitatif Lengkap - Uji Statistik." 2012.

[7] N. Rury, I. G. O. S. Pribadi, and D. Santoso, "Pengaruh Material Dan Bentuk Atap Rumah Tinggal Terhadap Suhu Di Dalam Ruang The Effect Of House Material And Roof Shape On Indoor Temperature," AGORA, vol. 15, no. 1, pp. 52-63, 2015.

[8] E. Wahyudi, "Pengaruh Bentuk Bukaan Atap Bangunan Terhadap Tingkat Kenyamanan Termal Pada Rumah Panjang Suku Dayak Brusu , Kecamatan Sekatak , Kalimantan Utara," Borneo Eng. J. Tek. Sipil, vol. 2, no. 2, pp. 94-104, 2018. 